PRACE GEOGRAFICZNE

zeszyt 159, 2019, 7-24

doi: 10.4467/20833113PG.19.017.11485

Instytut Geografii i Gospodarki Przestrzennej UJ

Komisja Geograficzna, Polska Akademia Umiejętności

Wydawnictwo Uniwersytetu Jagiellońskiego

\title{
WEWNĘTRZNA SAMOCHODOWA DOSTĘPNOŚĆ TRANSPORTOWA ŁODZI W ŚWIETLE POMIARÓW Z INTELIGENTNYCH SYSTEMÓW TRANSPORTOWYCH
}

\author{
Marta Borowska-Stefańska, Michat Kowalski, Szymon Wiśniewski
}

\section{Internal car transport accessibility of Łódź in the light of measurements from intelligent transportation systems}

Abstract: The paper deals with the topic of transport accessibility of Łódź using data from Intelligent Transportation Systems, in this case from cameras allowing automatical identification of number plates (ANPR), locatedon the city's 23 intersections. The paper has two aims. The first one is of methodological nature and focuses on assessing the usefulness of the data from ITS for geographical research. Not only does the paper present some ways of using data and conducting analyses with the use of these data but it also compares their results with research concerning similar phenomena measured by different sets of data (theoretical accessibility and data obtained from the Distance Matrix Responses provided by Google Maps APIs). The latter, in turn, is cognitive and it comes down to a slightly more local dimension, namely showing the internal transport accessibility of Łódź. In the light of the ANPR data it was determined that the internal transport accessibility of Łódź is much worse than the theoretical accessibility or the accessibility measured with the use of data obtained from the Distance Matrix service. The greatest differences in average travel times between the data from ANPR and the two remaining methods concern primarily the north-western part of the city, whereas the smallest - the central and southern areas, where a substantial part of intersections is covered by a system of cameras.

Keywords: transport geography, transport accessibility, car speed model, ITS, ANPR, Łódź 
Zarys treści: W artykule zajęto się zagadnieniem dostępności transportowej Łodzi, przy wykorzystaniu danych z Inteligentnych Systemów Transportowych, w tym przypadku z kamer umożliwiających automatyczną identyfikację tablic rejestracyjnych (ang. Automatic number-plate recognition, ANPR), rozmieszczonych na 23 skrzyżowaniach w mieście. W artykule postawiono dwa cele. Pierwszy z nich, o charakterze metodologicznym, skupia się na ocenie przydatności danych z ITS w badaniach geograficznych. W ramach jego realizacji nie poprzestano na przedstawieniu sposobu wykorzystania danych i dokonaniu za ich pomocą analiz, ale także porównano ich wyniki z badaniami dotyczącymi podobnych zjawisk mierzonych za pomocą innych zestawów danych (dostępności teoretycznej i danych zaczerpniętych z usługi Distance Matrix Responses świadczonej przez Google Maps APIs). Drugi z celów ma charakter poznawczy i jest sprowadzony do nieco bardziej lokalnego wymiaru - do ukazania wewnętrznej dostępności transportowej Łodzi. W wyniku przeprowadzonych badań stwierdzono, że wewnętrzna dostępność transportowa Łodzi, w świetle danych ANPR, jest znacznie gorsza od dostępności teoretycznej oraz gorsza od dostępności mierzonej za pomocą danych z usługi Distance Matrix Responses. Największe różnice w średnich czasach przejazdu pomiędzy danymi z ANPR a pozostałymi dwoma metodami dotyczą przede wszystkim północno-zachodniej części miasta, najmniejsze z kolei obszaru centralnego i południowego, gdzie znaczna część skrzyżowań objęta jest systemem kamer.

Stowa kluczowe: geografia transportu, dostępność transportowa, model prędkości ruchu samochodowego, ITS, ANPR, Łódź

\section{Wstęp}

Dostępność transportowa jest ważnym wskaźnikiem wartościowania przestrzeni miejskiej (Radziński, Gadziński 2016). Im większa - tym teoretycznie wyższa powinna być renta gruntowa, gdyż dobra dostępność powoduje zmniejszenie kosztów transportu. W przypadku orientacji rynkowej lepsza dostępność bardzo często oznacza większy rynek. Dlatego też poznanie możliwie najbliższej prawdzie dostępności transportowej ma niezwykle duże znacznie dla, po pierwsze lokalnych władz, po drugie - użytkowników przestrzeni miejskiej.

Z uwagi na wspomnianą rolę dostępności warto przybliżyć, co kryje się pod tym pojęciem. Bywa ona określana na wiele sposobów (Rosik 2012; Wiśniewski 2015) i jak wskazuje laureat międzynarodowej nagrody geograficznej Le prix international de géographie Vautrin-Lud z 1993 r. Amerykanin Peter Gould (1969, s. 72) „dostępność jest grząskim pojęciem, którego każdy używa, choć brak jest jej ostatecznej definicji i sposobów jej pomiaru". W ujęciu naszych badań, wydaje się, iż najlepiej odzwierciedlającą dostępność transportową definicją jest ta, zaprezentowana przez Cauvin (2005), która dostępność definiuje jako mierzalną wielkość oddalenia między daną lokalizacją a miejscami, z którymi chce być powiązana wybranym środkiem transportu. Wydaje się, że najlepszą miarą owego oddalenia, w dzisiejszym świecie, w myśl aforyzmu „czas to pieniądz”, jest oddalenie czasowe (por. Śleszyński 2014). 
Ze względu na fakt, iż największe problemy stwarza pomiar dostępności czasowej samochodowej (w badaniach makroskalowych często nazywaną dostępnością drogową) (Komornicki i in. 2010), właśnie ten środek transportu wybrano do dalszych analiz. Kwestia związana z lokalizacją miejsca, z którego i/lub do którego badane są powiązania, ma znaczenie kluczowe w przypadku badań szczegółowych (Borowska-Stefańska 2016; Kowalski, Wiśniewski 2017a), zaś w przypadku badań o charakterze ogólnym - najczęściej stosuje się topologiczne miary dostępności (Wiśniewski 2016) i tego typu miarę zastosowano w prezentowanych badaniach.

Generalnie rzecz biorąc, kwestią podstawową w badaniu dostępności czasowej jest określenie prędkości przemieszczania się uczestników systemu transportowego. W celu jej określenia dokonuje się wielu różnych sposobów pomiaru lub założeń mających ugruntowanie w teorii. Skoro więc przyjmujemy, że głównym celem nauki jest zobrazowanie prawdy i że z racji na złożoność systemu społecznego trudno doszukiwać się uniwersaliów w zakresie prędkości przemieszczania się (każdy użytkownik systemów transportowych ma możliwość doboru wielu rozwiązań w zakresie wyboru środka transportu, a także jest na swój sposób bytem zdeterminowanym między innymi przez własne przyzwyczajenia, temperament oraz miejsce w systemie społecznym), należy wciąż wyszukiwać nowe sposoby na uchwycenie chociażby ogólnych wskaźników w tym zakresie. Dodatkowo, wpływ na prędkość przemieszczania się ma bieżące natężenie na drogach, które może oprócz spowolnienia ruchu doprowadzić do zjawiska kongestii. W zasadzie to właśnie obciążenie w systemie miejskim ma istotny wpływ na prędkość ruchu. Dlatego też proponujemy zastanowienie się nad wykorzystaniem danych pochodzących z coraz liczniej funkcjonujących w polskich miastach inteligentnych systemów transportowych (ITS).

W ramach wspomnianych systemów wykorzystuje się między innymi kamery umożliwiające automatyczną identyfikację tablic rejestracyjnych (ang. automatic number-plate recognition, ANPR). Na podstawie danych pochodzących z systemu opartego na tym sposobie pomiaru możliwe staje się obliczenie czasu przejazdu pojedynczych samochodów na poszczególnych odcinkach sieci drogowej, co po prostych obliczeniach umożliwia ukazanie efektywnej prędkości przemieszczania się samochodem.

Zaprezentowanym badaniom przyświecały dwa podstawowe cele. Pierwszy z nich, o charakterze metodologicznym, skupia się na ocenie przydatności danych z ITS w badaniach geograficznych. W ramach jego realizacji nie poprzestano na przedstawieniu sposobu wykorzystania danych i dokonaniu za ich pomocą analiz, ale także porównano ich wyniki z badaniami dotyczącymi podobnych zjawisk mierzonych za pomocą innych zestawów danych. Drugi z celów ma charakter poznawczy i jest sprowadzony do nieco bardziej lokalnego wymiaru - do ukazania wewnętrznej dostępności transportowej Łodzi. Przetworzone bazy danych, zbudowany model sieci transportowej itp., powstałe w celu realizacji prezentowanych badań, mają także 
na celu służyć w dalszych pracach autorów dotyczących mobilności i dostępności transportowej - w tym będą stanowić fragment modelu sieci transportowej wykorzystanego na potrzeby pracy doktorskiej pisanej przez jednego ze współautorów opracowania.

\section{Przegląd literatury}

Modele prędkości przyjmowane w badaniach dostępności są zróżnicowane. Wspomniane różnice wynikają z dwóch zasadniczych kwestii: dostępu do danych oraz przestrzennego zasięgu analizy. Ograniczony dostęp do danych determinuje badacza do zastosowania różnego rodzaju rozwiązań polegających na uproszczeniach modeli ukazujących prędkość. Rozległy zasięg przestrzenny analiz prowadzi z kolei do korzystania z danych uogólnionych, ze względu na fakt, iż napotkać można problemy związane z kompatybilnością i porównywalnością zestawów danych reprezentujących różne obszary, a także z uwagi na techniczne możliwości ich wykonania przy założeniu wykorzystania zbyt szczegółowych informacji.

W efekcie, w literaturze spotyka się podejścia związane z szacowaniem prędkości ruchu i czasu przejazdu, oparte na danych: przepisów prawa o ruchu drogowym (Wiśniewski 2014), pozyskanych poprzez bezpośredni (na swój sposób subiektywny) pomiar wykonywany przez badacza biorącego udział w procesie przemieszczania się wzdłuż określonej sieci dróg (Bartosiewicz, Pielesiak 2012), obrazujących zarówno prędkości kodeksowe, kategorie dróg, ukształtowanie powierzchni terenu w ich otoczeniu, liczby mieszkańców w pobliżu drogi (Komornicki i in. 2010; Śleszyński 2016) oraz położenia względem obszarów rozwiniętych (Stępniak i in. 2013), związanych z natężeniem ruchu (Akcelik 1988), a także dotyczących historycznych czasów przejazdu zbieranych przez globalne korporacje, np. Google (Wiśniewski 2016) i operatorów sieci komórkowych (Bar-Gera 2007).

Oczywiście mając na uwadze to, co napisano we wstępie, żadna z nich nie jest w stanie w sposób w pełni rzeczywisty zobrazować zjawisko przemieszczania się pojazdów w sieci drogowej.

Przeciętne prędkości przyjmowane w badaniach nad dostępnością samochodową podlegają zmianom w czasie. Wspomniane zmiany nie są jednakowe dla każdej z klas dróg. Jak wynika z przeglądu literatury wykonanego przez Fröhlicha i Axhausena (2002, 2004), w szwajcarskich modelach prędkości ruchu w latach 1950-2000 nastąpiło zwiększenie prędkości ruchu na większości dróg poza obszarem zabudowanym, zaś na odcinkach miejskich nie zaobserwowano zmian (przez cały okres na głównych drogach w miastach przyjmowano prędkość 22 km/h). Bateman z zespołem (1996, 1999), budując model prędkości, w swoich badaniach posiłkowali się danymi z oficjalnych źródeł danych z departamentu transportu, które następnie weryfikowali 
i porównywali z prędkościami uzyskiwanymi w innych badaniach (w tym pozyskanych z aplikacji służących planowaniu tras). Dalszą kalibrację modelu opierali o swoje osobiste doświadczenia. W efekcie stwierdzili, że oficjalne dane są znacznie zawyżone. Ostatecznie w modelu założyli prędkości dość znacznie skorygowane (tab. 1).

Tab. 1. Prędkości wykorzystane w modelu zespołu Batemana (1996) na poszczególnych kategoriach dróg na obszarach zurbanizowanych oraz wynikające z oficjalnych danych z Departamentu Transportu

Table 1. Speed used in the model of Bateman et al. (1996) on individual road categories in urbanized areas and resulting from the official data of the Department of Transport (DoT)

\begin{tabular}{|l|c|c|}
\hline \multicolumn{1}{|c|}{$\begin{array}{c}\text { Rodzaj drogi } \\
\text { Road type }\end{array}$} & $\begin{array}{c}\text { Średnie prędkości oparte na } \\
\text { oficalnych danych z Departamentu } \\
\text { Transportu [km/h] } \\
\text { Average road speed } \\
{[\mathrm{km} / \mathrm{h}] \text { (DoT estimates) }}\end{array}$ & $\begin{array}{c}\text { Średnie prędkości przyjęte } \\
\text { w modelu [km/h]; } \\
\text { wg Batman i in. 1996 } \\
\text { Average road speed [km/h] } \\
\text { used by Bateman et al. 1996 }\end{array}$ \\
\hline $\begin{array}{l}\text { Autostrady } \\
\text { Motorway }\end{array}$ & 80,47 & 56,33 \\
\hline $\begin{array}{l}\text { Główne drogi dwujezdniowe (kat. A) } \\
\text { A-Road Primary Dual Carriageway }\end{array}$ & 64,37 & 45,06 \\
\hline $\begin{array}{l}\text { Inne drogi dwujezdniowe (kat. A) } \\
\text { A-Road Other Dual Carriageway }\end{array}$ & 56,33 & 40,23 \\
\hline $\begin{array}{l}\text { Główne drogi jednojezdniowe (kat. A) } \\
\text { A-Road Primary Single Carriageway }\end{array}$ & 56,33 & 40,23 \\
\hline $\begin{array}{l}\text { Inne drogi jednojezdniowe (kat. A) } \\
\text { A-Road Other Single Carriageway }\end{array}$ & 40,23 & 28,97 \\
\hline $\begin{array}{l}\text { Drogi dwujezdniowe (kat. B) } \\
\text { B-Road Dual Carriageway }\end{array}$ & 40,23 & 28,97 \\
\hline $\begin{array}{l}\text { Drogi jednojezdniowe (kat. B) } \\
\text { B-Road Single Carriageway }\end{array}$ & 27,36 & 19,31 \\
\hline $\begin{array}{l}\text { Drogi boczne (drugorzędne) } \\
\text { Minor Road }\end{array}$ & 24,14 & 17,7 \\
\hline
\end{tabular}

Źródto: Bateman i in., 1996, s. 197.

Source: Bateman et al., 1996, s. 197.

Z uwagi na różnorodność miejskich systemów transportowych należy zauważyć, iż bezpośrednie skorzystanie z modeli ruchu z innych miast może przynieść rezultaty odbiegające od rzeczywistości. Dlatego podjęliśmy się syntetycznego ukazania podejść badawczych i wyników różnego rodzaju pomiarów w zakresie prędkości poruszania się samochodów, które bardziej lub mniej pośrednio odnoszą się do przyjętego przez nas obszaru badań (tab. 2). 
Tab. 2. Porównanie wybranych modeli prędkości przyjmowanych w badaniach oraz wyniki badań nad prędkościami ruchu w mieście

Table 2. Comparison of selected models of speed adopted in research and results of research into traffic speed in the town

\begin{tabular}{|c|c|c|}
\hline $\begin{array}{l}\text { Źródło } \\
\text { Source }\end{array}$ & $\begin{array}{l}\text { Obszar } \\
\text { Area of coverage }\end{array}$ & $\begin{array}{l}\text { Prędkość } \\
\text { Speed }\end{array}$ \\
\hline Komornicki i in. 2010 & $\begin{array}{l}\text { Miasta grodzkie } \\
\text { City-country towns }\end{array}$ & $\begin{array}{c}\text { Zależna od kategorii drogi / Dependent on road category: } \\
\text { Autostrada / Motorway: } 110 \mathrm{~km} / \mathrm{h} \\
\text { Ekspresowa dwujezdniowa } \\
\text { Express dual carriageway: } 90 \mathrm{~km} / \mathrm{h} \\
\text { Ekspresowa jednojezdniowa } \\
\text { Express single carriageway: } 70 \mathrm{~km} / \mathrm{h} \\
\text { Inna dwujezdniowa / Other dual carriageway: } 50 \mathrm{~km} / \mathrm{h} \\
\text { Inna jednojezdniowa krajowa } \\
\text { Other national single carriageway: } 40 \mathrm{~km} / \mathrm{h} \\
\text { Inna jednojezdniowa wojewódzka } \\
\text { Other provincial single carriageway: } 30 \mathrm{~km} / \mathrm{h}\end{array}$ \\
\hline $\begin{array}{l}\text { Dąbrowska-Loranc } \\
\quad \text { i in. } 2015\end{array}$ & $\begin{array}{c}\text { Średnia dla miast } \\
\text { wojewódzkich } \\
\text { Average for voivodship } \\
\text { cities }\end{array}$ & $\begin{array}{l}\text { Pojazdy lekkie na ulicach dwujezdniowych w ciągu dnia } \\
\text { Light vehicles on dual carriageways during the day: } \\
59,9 \mathrm{~km} / \mathrm{h} \\
\text { Pojazdy ciężkie na ulicach dwujezdniowych w ciągu dnia } \\
\text { Heavy vehicles on dual carriageways during the day: } \\
58,1 \mathrm{~km} / \mathrm{h} \\
\text { Pojazdy lekkie na ulicach jednojezdniowych w ciągu dnia } \\
\text { Light vehicles on single carriageways during the day: } \\
55,1 \mathrm{~km} / \mathrm{h} \\
\text { Pojazdy ciężkie na ulicach jednojezdniowych w ciągu dnia } \\
\text { Heavy vehicles on single carriageways during the day: } \\
53,8 \mathrm{~km} / \mathrm{h}\end{array}$ \\
\hline $\begin{array}{l}\text { Bartosiewicz, } \\
\text { Pielesiak } 2012\end{array}$ & $\begin{array}{l}\text { Łódzki Obszar } \\
\text { Metropolitalny (ŁOM) - } \\
\text { Zbadano przemieszczanie } \\
\text { się od zewnętrznej granicy } \\
\text { gminy ościennej ŁOM } \\
\text { do wewnętrznej } \\
\text { obwodnicy Łodzi. } \\
\text { Łódź Metropolitan Area }\end{array}$ & $\begin{array}{l}\text { W godzinach szczytu / Rush hour: } V_{r}-16 \mathrm{~km} / \mathrm{h} \\
\text { Poza godzinami szczytu / Off-peak hours: } \\
\qquad V_{r}=V_{k}-8 \mathrm{~km} / \mathrm{h} \\
\text { Przeciętnie w ciągu dnia / Average during the day: } \\
\qquad V_{r}=V_{k}-12 \mathrm{~km} / \mathrm{h} \text { gdzie / where: } \\
V_{r}-\text { prędkość rzeczywista / actual speed } \\
V_{k} \text { - prędkość kodeksowa / codex speed }\end{array}$ \\
\hline $\begin{array}{l}\text { Borowska-Stefańska, } \\
\text { Wiśniewski } 2018\end{array}$ & Łódź & $\begin{array}{l}\text { Maksymalna dopuszczalna prędkość kodeksowa } \\
\text { Maximum permissible speed }\end{array}$ \\
\hline Korkowo.pl, 2017 & $\begin{array}{l}\text { Łódź - w ekwidystancie } \\
2 \mathrm{~km} \text { od centrum } \\
\text { Łódź - in the area up to } \\
2 \mathrm{~km} \text { from the city centre }\end{array}$ & $26 \mathrm{~km} / \mathrm{h}$ \\
\hline Korkowo.pl, 2017 & $\begin{array}{l}\text { Łódź - w ekwidystancie } \\
10 \mathrm{~km} \text { od centrum } \\
\text { Łódź - in the area up to } \\
10 \mathrm{~km} \text { from the city centre }\end{array}$ & $40 \mathrm{~km} / \mathrm{h}$ \\
\hline
\end{tabular}




\section{Charakterystyka obszaru badań}

Elementami łódzkiego układu drogowo-ulicznego, stanowiącymi nośnik relacji z systemami międzynarodowymi, krajowymi i regionalnymi są: odcinek autostrady A1 - we wschodniej części miasta, cztery drogi krajowe: 14, 71, 72 i 91, z których: 14 i 91 to drogi klasy głównej ruchu przyspieszonego, a 71 i 72 - to drogi klasy głównej. Ponadto przez miasto przebiegają dwie drogi wojewódzkie (zaliczane do klasy głównej z odcinkami klasy głównej ruchu przyspieszonego): 710 i 713. Łódzki układ transportowy przybiera formę kratownicową w śródmieściu i wraz z oddalaniem się od niego układ dróg staje się coraz mniej regularny ${ }^{1}$. Gęstość dróg kołowych w Łodzi ogółem wynosi $9,29 \mathrm{~km} / \mathrm{km}^{2}$, przy czym w poszczególnych dzielnicach wartości te kształtowały się następująco: Bałuty 10,2; Górna 9,34; Polesie 9,57; Śródmieście 12,69; Widzew 8,07.

W zakresie natężenia ruchu w Łodzi daje się zaobserwować, iż największe obciążenia przenoszone są przez wewnętrzną obwodnicę miasta (ring stanowiący jednocześnie elementy krajowego systemu dróg) oraz arterię łączącą dwa wielkie osiedla mieszkaniowe - Widzew na wschodzie z Retkinią na zachodzie (Kowalski, Wiśniewski 2017b). Wydaje się, że wspomniane drogi, stanowiące miejski układ podstawowy, w głównej mierze zbierają ruch międzydzielnicowy, zaś w obrębie każdej z dzielnic naczelną rolę w organizacji przepływów odgrywają drogi zbiorcze, które jak napisano wcześniej - wraz z drogami lokalnymi i dojazdowymi - przybierają regularny kształt kratownicy. Z uwagi na dość znaczne oddalenie wspomnianego układu podstawowego od śródmieścia w centralnej części miasta daje się zaobserwować duże, jak na kategorie dróg w nim występujące, obciążenie powodujące liczne problemy, w tym zjawisko kongestii. $Z$ tego też powodu w grudniu 2015 r. w mieście wdrożono Obszarowy System Sterowania Ruchem, który swoim zasięgiem obejmuje w zasadzie całość śródmiejskiego układu transportowego (ryc. 2) oraz wybrane, newralgiczne odcinki dróg w pozostałych dzielnicach (Kowalski, Wiśniewski 2017b). System ten, w zakresie transportu samochodowego oparty jest na pomiarach z pętli indukcyjnych oraz kamer ANPR (Borowska-Stefańska i in. 2019), a jego podstawowym celem jest zwiększenie płynności ruchu w granicach miasta i poprawa efektywności transportu publicznego. Jak pokazują analizy natężenia ruchu, liczba pojazdów na drogach w Łodzi, w głównej mierze związana jest z mobilnością w tygodniu roboczym, zaś najmniejszy ruch obserwowany jest w weekendy. Nadmierne obciążenie układu transportowego obserwuje się w godzinach porannego (godziny 7:15-9:00) i popołudniowego szczytu (godziny 14:00-18:15) (Kowalski, Wiśniewski 2017b).

\footnotetext{
${ }^{1}$ Struktura przestrzenna Łodzi w ujęciu generalnym składa się z dwóch zasadniczych części: śródmieścia (w granicach pokrywających się z łódzką koleją obwodową) i dzielnic zlokalizowanych poza granicami kolei obwodowej (Lamprecht, Wojnarowska 2013). Wspomniane granice w zasadzie pokrywają się z miejscem, w którym układ drogowy w sposób zasadniczy zmienia swój kształt.
} 


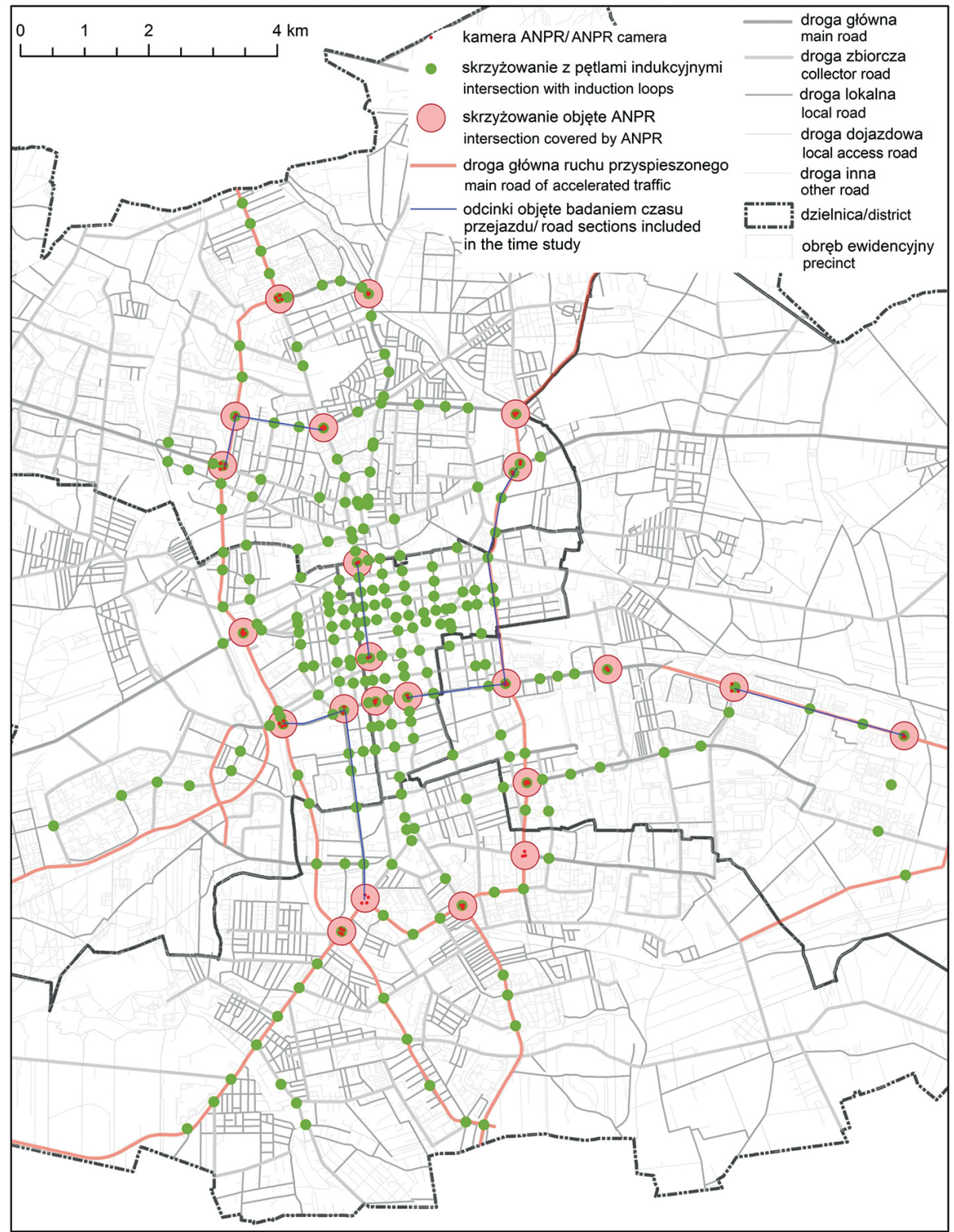

Ryc. 2. Monitoring ITS w łódzkiej sieci dróg oraz odcinki dróg poddane dalszym analizom Źródto: opracowanie własne oraz Kowalski, Wiśniewski 2017b, s. 22.

Fig. 2. ITS monitoring in the road network of Łódź and road sections subjected to further analysis

Source: own study and Kowalski, Wiśniewski 2017b, s. 22. 


\section{Metody i źródła danych}

W badaniach posłużono się metodą badania dostępności izochronowej (kumulatywnej). Wszelkie analizy dostępności wykonano wykorzystując narzędzia oferowane przez oprogramowanie GIS - ArcMap (ryc. 1).

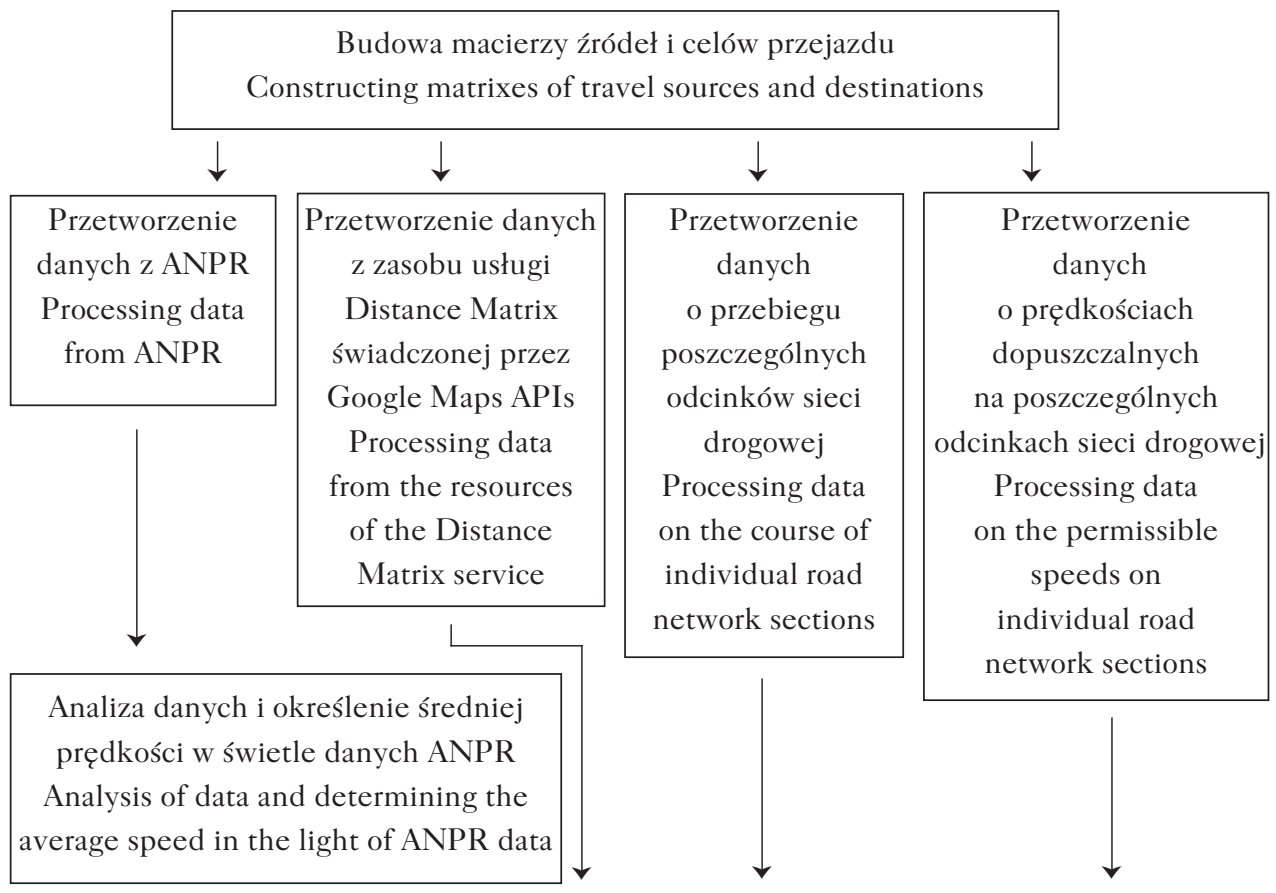

Budowa wirtualnej sieci transportowej uwzględniającej prędkości poruszania się w każdym z badanych wariantów

Constructing a virtual transport network accounting for travel speed in each researched variant

Tworzenie zestawień w celu pokazania różnic w dostępności czasowej
z uwzględnieniem poszczególnych źródeł danych
Creating juxtapositions in order to demonstrate differences in time accessibility
taking into account individual sources of data
$\downarrow$
Zestawienie przebiegu izochron w poszczególnych wariantach badanej dostępności
z zagospodarowaniem terenu
Juxtaposing the course of isochrones in individual variants of analysed accessibility
with land development

Ryc. 1. Schemat postepowania badawczego

Fig. 1. Scheme of the research proceeding 
Śleszyński (2014) wskazuje na trzy grupy wskaźników dostępności: częstotliwość środka transportu, dostępność czasową do środka transportu oraz dostępność czasową przemieszczania się środkami transportu. Badania prezentowane w niniejszym artykule mieszczą się w trzeciej z nich i obejmują jedynie określanie czasu potrzebnego na samo poruszanie się - nie całej podróży (czas jazdy brutto).

$\mathrm{Na}$ obszarze miasta wyznaczono oddalone od siebie, w równych odległościach euklidesowych, punkty (291), z których każdy stanowił zarówno źródło, jak i cel podróży. W efekcie otrzymano macierz 291 na 291 obiektów.

Autorzy wykorzystali dane przekazane przez Urząd Miasta Łodzi (na potrzeby badań nad dostępnością i mobilnością w Łodzi) jednostce organizacyjnej, w której są zatrudnieni. Wspomniane materiały dotyczą zanonimizowanych pomiarów (zmieniono w nich względem oryginalnego zapisu identyfikatory pojazdów, tj. zastąpiono oznaczenia tablic rejestracyjnych unikalnym dla każdej z nich kodem) pochodzących z kamer ANPR rozmieszczonych w łódzkiej sieci transportowej (Borowska-Stefańska i in. 2019). Przetworzenie wspomnianych danych dotyczyło przypisania każdej z kamer odpowiednich współrzędnych w celu umiejscowienia ich w modelu sieci transportowej oraz wybór okresów uwzględnionych w analizie (godziny porannego i popołudniowego szczytu oraz godziny w ciągu dnia poza szczytem).

Następnie wybrano drogi według ich klas i umiejscowienia w strukturze przestrzennej miasta, stanowiące próbę, na której zmierzono szybkość przejazdu, a wyniki rozszerzono na całą zbiorowość dróg danej klasy w określonych dwóch lokalizacjach². Wyjątkiem od tej reguły są drogi klasy głównej i zbiorczej poza centrum miasta oraz drogi klas lokalnej i dojazdowej, dla których prędkości oszacowano na podstawie procedury opisanej w dalszej części pracy3. Wybór odcinków dróg został wykonany zgodnie z podstawową przesłanką - ciągłość pomiaru kamer ANPR wzdłuż odcinka drogi. W efekcie do dalszych prac wytypowano odcinki drogowe, w których możliwy był pomiar czasu przejazdu na drogach głównych ruchu przyspieszonego w centrum miasta, drogach głównych ruchu przyspieszonego poza centrum, drogach głównych i zbiorczych w centrum (ryc. 2). Następnie poddano analizie wyniki pomiarów w celu usunięcia tych, które nie wynikały z bezpośredniego przejazdu pomiędzy kamerami (np. przejazd z postojem wzdłuż odcinka). Analizy wykonano wykorzystując wizualizację poszczególnych danych na wykresie punktowym. Przyjęto, iż w przypadku rzeczywistego - nieprzerwanego przejazdu pojazdu - będzie można go zaobserwować na wykresie przedstawiającym wyniki pomiarów uporządkowane w szeregu prostym (wg rosnących czasów przejazdu). Tym samym z zestawu danych pozbyto się, obok przejazdów o charakterze innym niż bezpośredni, także błędów

\footnotetext{
${ }^{2}$ Za granicę pomiędzy centrum a obszarami położonymi poza nim uznano linię kolei obwodowej. ${ }^{3}$ Wspomniane wyjątki są pochodną rozmieszczenia aparatury ITS w Łodzi, tj. brakiem objętych pomiarem odcinków wspomnianych klas dróg w danych lokalizacjach.
} 
pomiarowych wynikających z ewentualnego niedokładnego odczytania numeru tablic rejestracyjnych pojazdu.

W kolejnym etapie przeliczono dystans i czas przejazdu pomiędzy kamerami ANPR wyselekcjonowanych pojazdów, uzyskując w efekcie prędkość przejazdu poszczególnych odcinków. Każdy z odcinków został przebadany w okresie dwóch szczytów transportowych oraz w czasie pomiędzy nimi. Następnie poddano uśrednianiu prędkości przejazdu z uwagi na dość znaczną rozpiętość pomiędzy obserwacjami w różnych okresach. W dalszej kolejności odniesiono te wartości do wartości prędkości wynikających z modelu opartego na prędkościach kodeksowych $\left(\mathrm{v}_{\text {ANPR }} \div \mathrm{v}_{k}\right) \times 100 \%$. W efekcie uzyskano informację, jaki procent prędkości kodeksowej jest realizowany w zakresie zmierzonych przemieszczeń na poszczególnych klasach dróg z uwzględnieniem ich umiejscowienia. Następnie oszacowano, o ile zmniejsza się prędkość względem prędkości kodeksowej na drogach klasy głównej i zbiorczej poza centrum miasta, odnosząc wspomniane prędkości proporcjonalnie do prędkości obserwowanych na wyższej klasie dróg $\left(\mathrm{v}_{\text {out }}=\left(\mathrm{v}_{\text {in }} \times \mathrm{v}_{\text {out }}\right) \div \mathrm{v}_{\text {in }}\right)$. Dla klas dróg: lokalnej i dojazdowej zastosowano względne prędkości z wyników dotyczących klas dróg zbiorczych, z uwagi na ich wzajemne podobieństwo. Ostatecznie względne prędkości poruszania się po sieci łódzkich dróg wskazują, iż im wyższa klasa drogi, tym mniejsze straty obserwowanych prędkości względem prędkości kodeksowej oraz, że poza centralną częścią miasta uwidaczniają się mniejsze straty czasu (tab. 3).

Tab. 3. Efektywne prędkości samochodów w świetle danych ANPR a klasy dróg i ich lokalizacja w łódzkiej sieci drogowej

Table 3. Effective car speed in the light of ANPR data versus road classes and their location in the road network of Łódź

\begin{tabular}{|c|c|c|}
\hline $\begin{array}{c}\text { Lokalizacja } \\
\text { Location }\end{array}$ & $\begin{array}{c}\text { Klasa drogi } \\
\text { Type of road }\end{array}$ & $\begin{array}{c}\text { Prędkość } \\
\text { Speed }\end{array}$ \\
\hline \multirow{4}{*}{$\begin{array}{c}\text { Centrum miasta } \\
\text { City centre }\end{array}$} & $\begin{array}{c}\text { główna ruchu przyspieszonego } \\
\text { main road of accelerated traffic }\end{array}$ & $\mathrm{V}=\mathrm{V}_{\mathrm{k}} \times 0,419$ \\
\cline { 2 - 3 } & główna / main road & $\mathrm{V}=\mathrm{V}_{\mathrm{k}} \times 0,338$ \\
\cline { 2 - 3 } & zbiorcza / collector road & $\mathrm{V}=\mathrm{V}_{\mathrm{k}} \times 0,251$ \\
\cline { 2 - 3 } & lokalna i dojazdowa / local and access road & $\mathrm{V}=\mathrm{V}_{\mathrm{k}} \times 0,251$ \\
\hline \multirow{4}{*}{$\begin{array}{c}\text { Peryferie } \\
\text { Periphery }\end{array}$} & $\begin{array}{c}\text { główna ruchu przyspieszonego } \\
\text { main road of accelerated traffic }\end{array}$ & $\mathrm{V}=\mathrm{V}_{\mathrm{k}} \times 0,661$ \\
\cline { 2 - 3 } & główna / main road & $\mathrm{V}=\mathrm{V}_{\mathrm{k}} \times 0,532$ \\
\cline { 2 - 3 } & zbiorcza / collector road & $\mathrm{V}=\mathrm{V}_{\mathrm{k}} \times 0,395$ \\
\cline { 2 - 3 } & lokalna i dojazdowa / local and access road & $\mathrm{V}=\mathrm{V}_{\mathrm{k}} \times 0,395$ \\
\hline
\end{tabular}


Wspomniane wyżej prędkości posłużyły do budowy wirtualnej sieci dróg, powstałej na podstawie zestawów danych zawierających cechy geometryczne łódzkiego systemu transportowego. W jej skład, poza prędkościami określonymi na podstawie analiz danych pochodzących z ITS, zostały uwzględnione prędkości kodeksowe i te, oparte na danych z usługi Distance Matrix Responses świadczonej przez Google Maps APIs. Pierwsze z nich - prędkości kodeksowe to nic innego jak prędkości wynikające z kodeksu drogowego i (BDOT). Drugie z nich zostały scharakteryzowane jako źródła danych przez Wiśniewskiego (2016).

Dalsza część prac badawczych skupiała się na ukazaniu różnic w pomiarze dostępności przy wykorzystaniu trzech wcześniej wspomnianych źródeł danych, przy czym porównano jedynie wyniki oparte na danych ITS z pozostałymi źródłami. W zakresie porównań, poza kwestiami przebiegów poszczególnych izochron, zaprezentowano wyniki dostępności uwzględniające charakter zabudowy w Łodzi, rozpoznany w badaniu na podstawie danych BDOT.

Poddając interpretacji rysunki przedstawiające dostępności topologiczne wyznaczone na podstawie różnych zestawów danych, należy zwrócić szczególną uwagę na przedziały klasowe, które z uwagi na duże zróżnicowanie wyników przybierają różne postacie dla każdej z map, a ich ujednolicenie doprowadziłoby do znaczących problemów w zakresie interpretacji zróżnicowania przestrzennego dostępności w ujęciu każdej z metod.

\section{Wyniki}

Wyniki badań dostępności czasowej uwzględniające model prędkości na podstawie ANPR wskazują na znacznie większą niż w przypadku badań opartych na pozostałych źródłach danych, tendencję do kształtowania się łódzkiej struktury urbanistycznej w układy pasmowe (ryc. 3). Co ciekawe, większość z pasm - z przestrzennego punktu widzenia-ukształtowało się na podstawie „starej”, powstałej jeszcze przed okresem transformacji ustrojowej, infrastruktury transportowej. Wyjątkiem jest niedawno powstała „trasa Górna”. Źródeł takiego, a nie innego kształtowania się pasm należy upatrywać w koncentryczności układu podstawowego miasta oraz nieciągłości na linii nowa - stara infrastruktura transportowa obserwowanej w centralnej części miasta.

Różnice w pomiarze wewnętrznej dostępności czasowej Łodzi (ryc. 4), wynikające $\mathrm{z}$ zastosowania różnych modeli prędkości, wskazują na duże zróżnicowanie przestrzenne. 


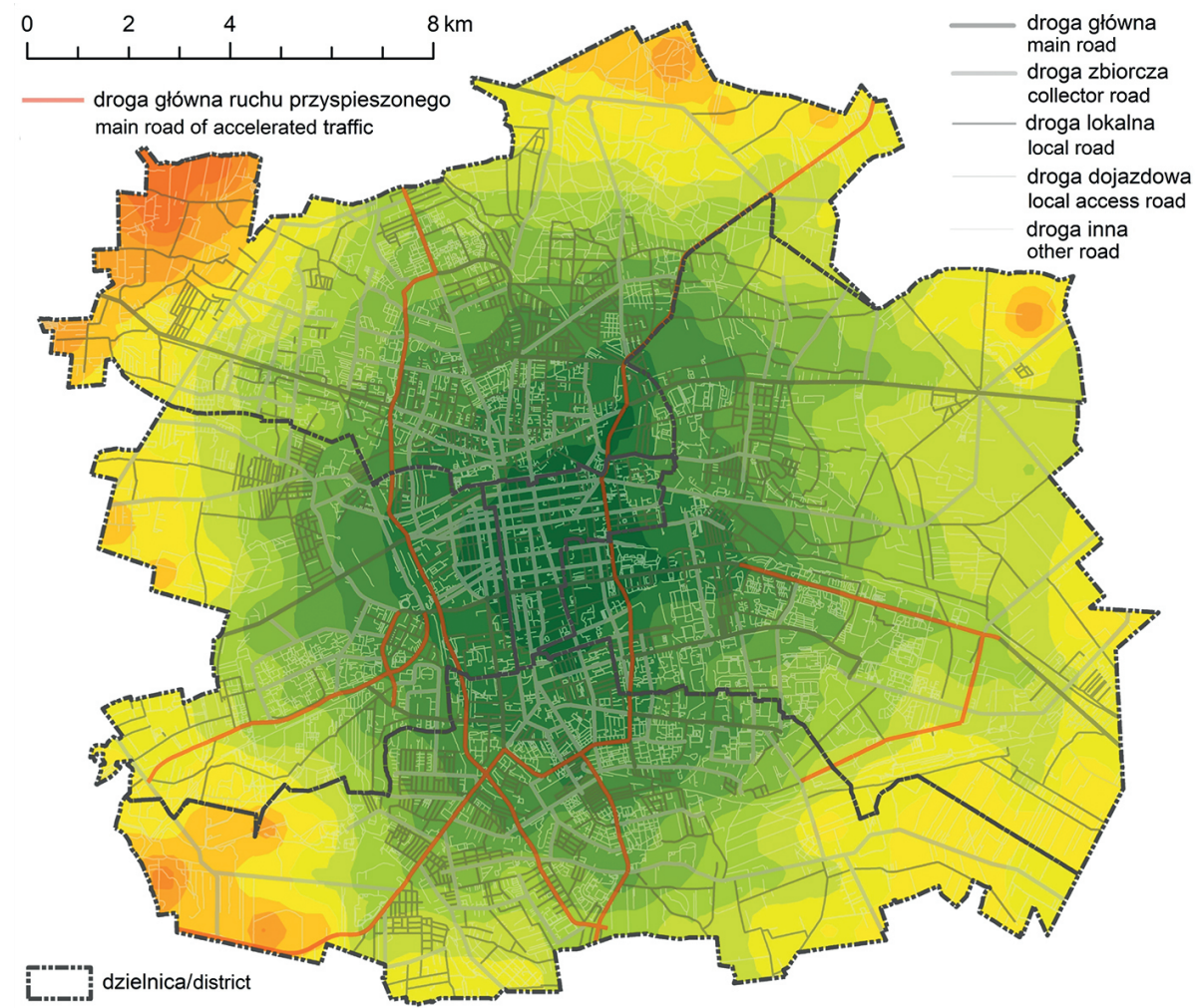

topologiczny czas przejazdu [godziny]/topological travel time [hours]

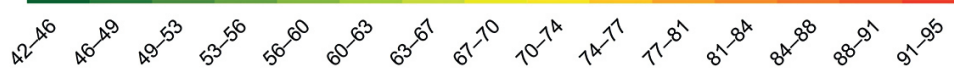

Ryc. 3.1. Wewnętrzna dostępność transportowa Łodzi w ujęciu topologicznym przy zastosowaniu prędkości kodeksowych

Fig. 3.1. Internal transport accessibility of Łódź from the topological perspective with the use of codex speeds 


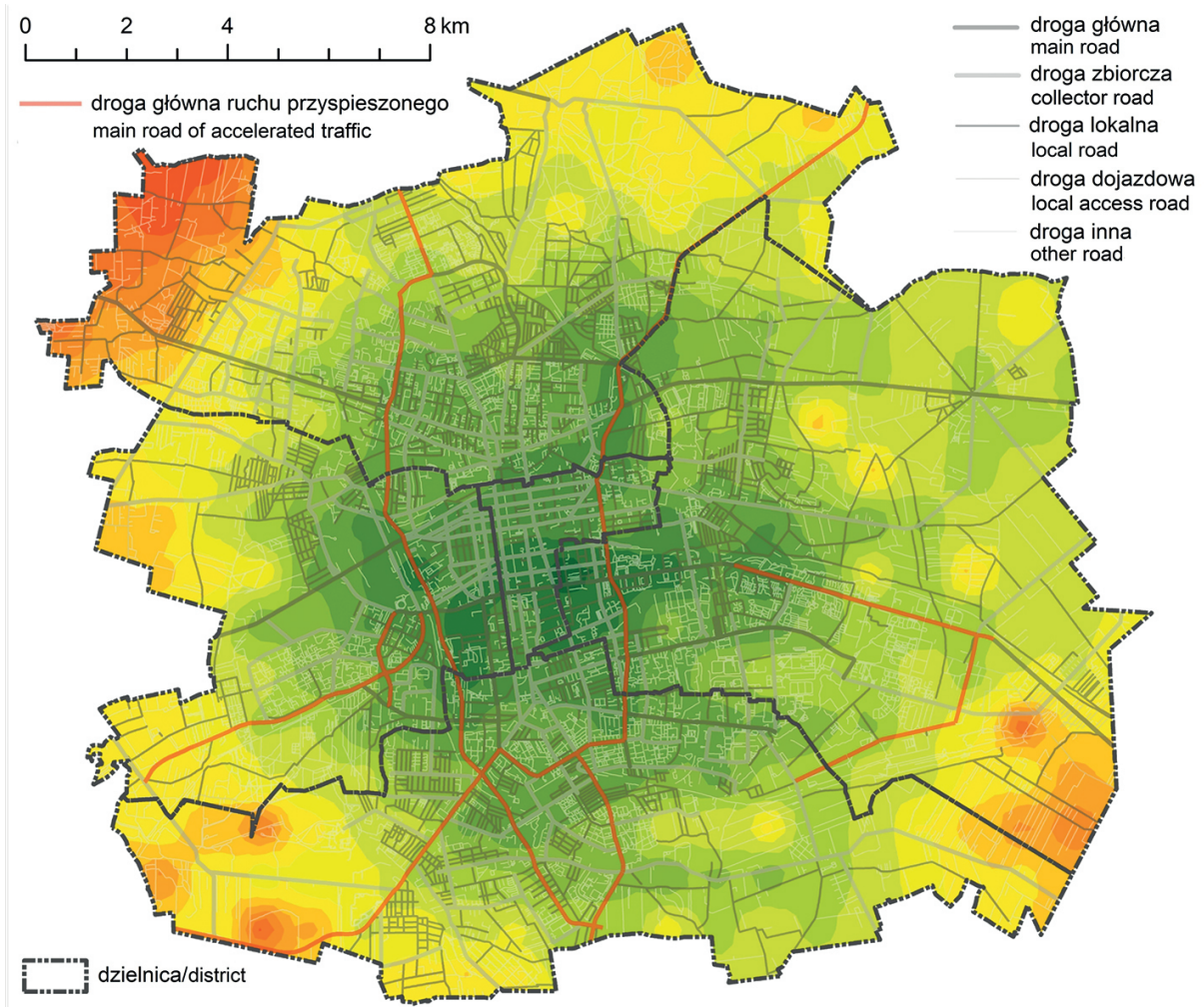

topologiczny czas przejazdu [godziny]/topological travel time [hours]

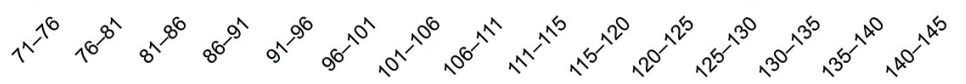

Ryc. 3.2. Wewnętrzna dostępność transportowa Łodzi w ujęciu topologicznym przy zastosowaniu danych z usługi Distance Matrix Responses świadczonej przez Google Maps APIs Fig. 3.2. Internal transport accessibility of Łódź from the topological perspective with the using data form the Distance Matrix Responses provided by Google Maps APIs 


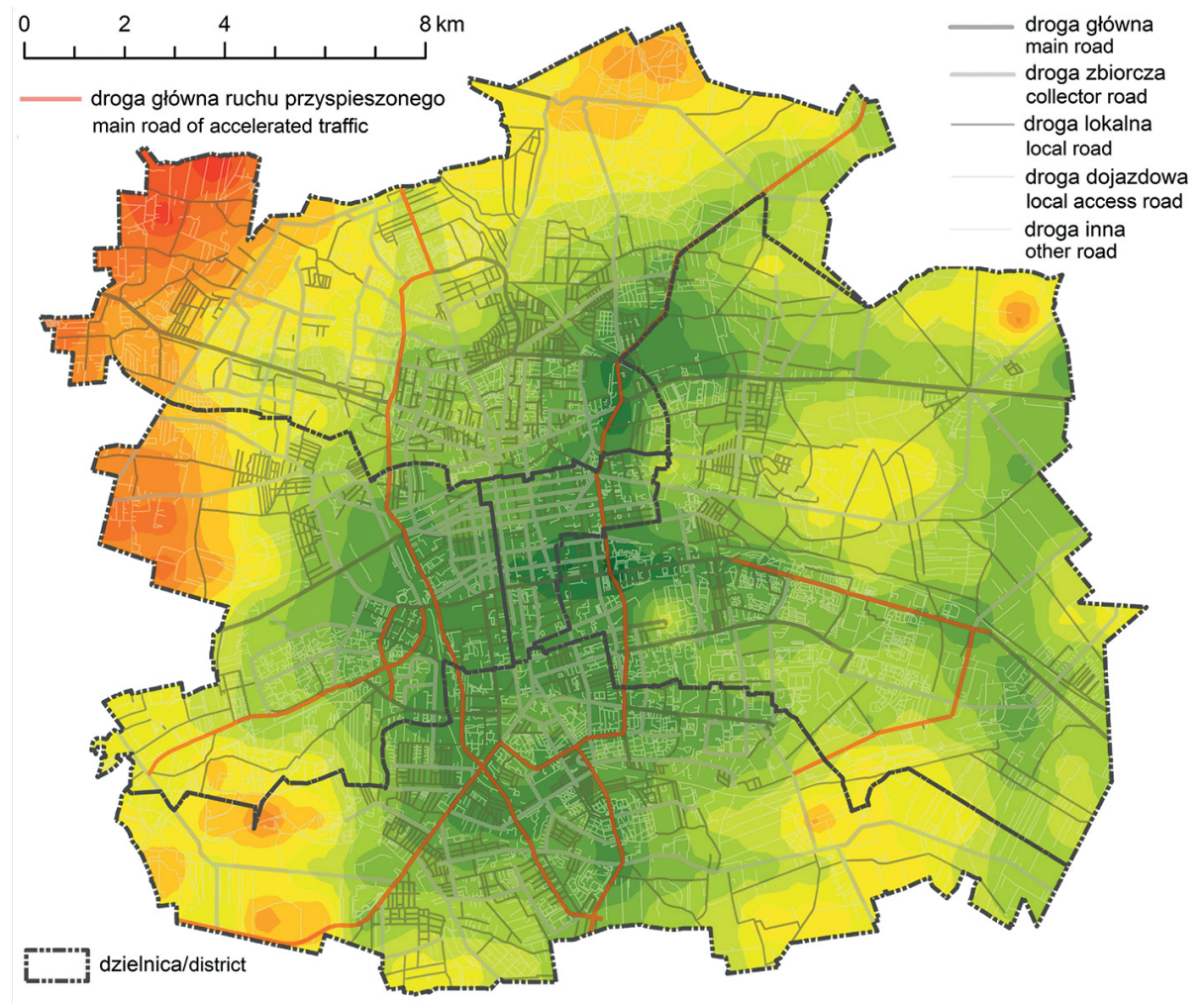

topologiczny czas przejazdu [godziny]/topological travel time [hours]

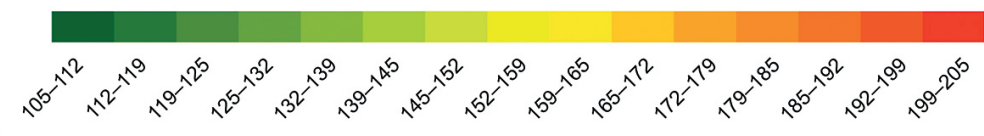

Ryc. 3.3. Wewnętrzna dostępność transportowa Łodzi w ujęciu topologicznym w świetle danych ANPR

Fig. 3.3. Internal transport accessibility of Łódź from the topological perspective in the light of the ANPR data 


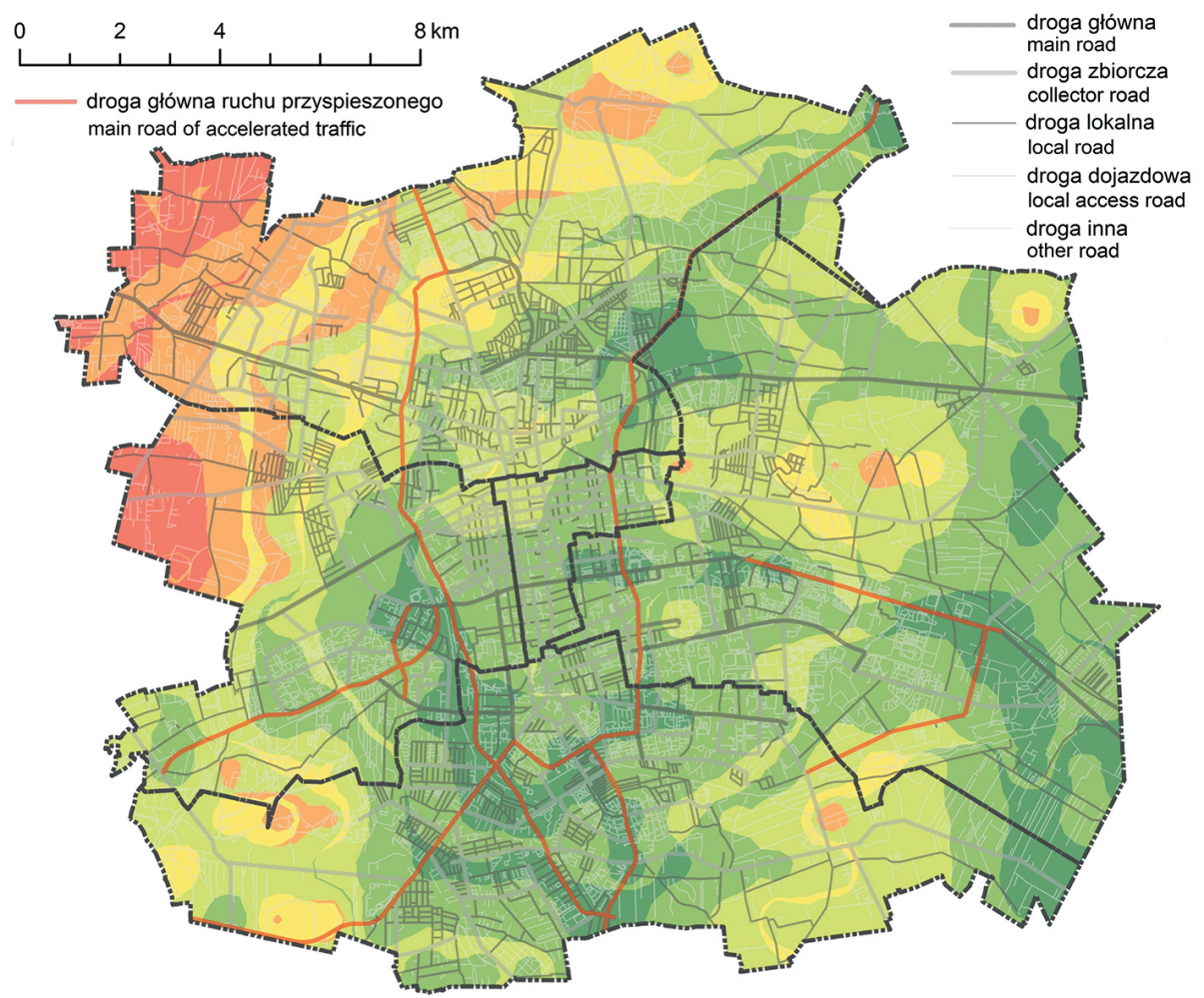

różnica średniego czasu przejazdu [minuty]/difference in average travel time [minutes]

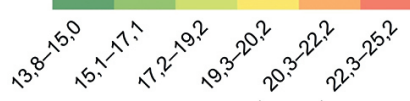

L...." dzielnica/district

Ryc. 4.1. Różnica wewnętrznej dostępności transportowej Łodzi mierzona na podstawie danych ANPR względem dostępności teoretycznej

Fig. 4.1. Difference of the internal transport accessibility of Łódź measured on the basis of ANPR data in relation to theoretical accessibility 


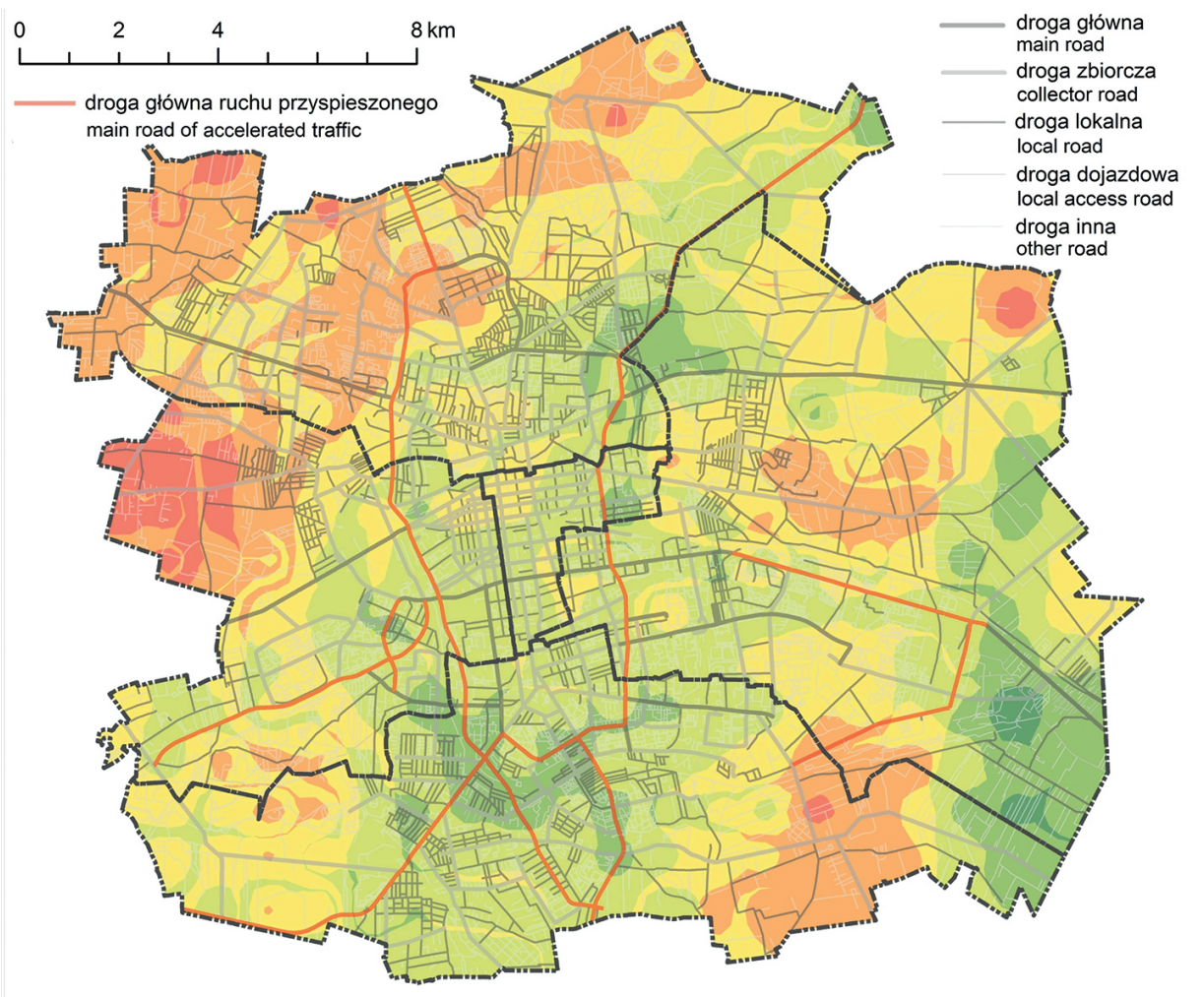

różnica średniego czasu przejazdu [minuty]/difference in average travel time [minutes]

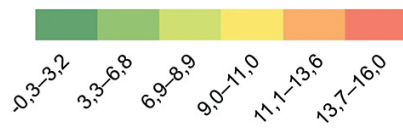

dzielnica/district

Ryc. 4.2. Różnica wewnętrznej dostępności transportowej Łodzi mierzona względem danych z usługi Distance Matrix Responses świadczonej przez Google Maps APIs

Fig. 4.2. Difference of the internal transport accessibility of Łódź measured relative to the data from the Distance Matrix Responses provided by Google Maps APIs 
Największe różnice występują pomiędzy badaniem opartym na założeniu prędkości kodeksowej względem prędkości szacowanych na podstawie danych ANPR. Występują one w śródmieściu, w pasmach wzdłuż dróg krajowych w dzielnicy Górna oraz wzdłuż ul. Strykowskiej i Inflanckiej oraz na wschodnich rubieżach Łodzi. Największe obszarowo różnice zauważane są na terenach oznaczonych izochronami wskazujących na przedziały średnich różnic w dostępności topologicznej pomiędzy 15,1-17,1 min oraz 17,2-19,2 min (tab. 4). Na tych obszarach dominuje zabudowa mieszkaniowa wielorodzinna (kolejno 50\% i 68\% zabudowy), co jest wynikiem kształtowania rozbudowy miasta wzdłuż głównych ciągów transportowych, które w największym stopniu wpływają na różnice dostępności. Największe udziały zabudowy jednorodzinnej (92\%) obserwowane są w przedziale różnic dostępności powyżej 22,3 min (najmniej rozległych) i występują na obszarach zachodnich suburbiów. Analizując szczegółowo funkcje i rozmieszczenie budynków względem różnic pomiarów dostępności, należy zauważyć, że w izochronie 15,1-17,1 znajduje się nieco ponad 50\% budynków handlowo-usługowych i jednorodzinnych oraz $58 \%$ wszystkich budynków wielorodzinnych i aż $63 \%$ przemysłowo-składowych.

Różnice pomiaru dostępności transportowej, mierzone na podstawie danych z korporacji Google i danych ANPR, są znacznie mniejsze. W przypadku tego porównania dostrzega się, iż w przestrzeni Łodzi znajdują się miejsca o lepszej dostępności okre-

Tab. 4. Różnica pomiędzy wewnętrzną dostępnością transportową Łodzi określoną przy użyciu prędkości kodeksowej a wynikami opartymi na danych z ANPR - kontekst zagospodarowania Table 4. Difference between the internal transport accessibility of Łódź determined with the use of the codex speed and the results based on the ANPR data - the context of land development

\begin{tabular}{|c|c|c|c|c|c|r|}
\hline $\begin{array}{c}\text { Różnica } \\
\text { średniego } \\
\text { czasu } \\
\text { [godz.] } \\
\text { Difference } \\
\text { in average } \\
\text { time [hrs.] }\end{array}$ & $\begin{array}{c}\text { Pozostała } \\
\text { zabudowa }\left[\mathrm{km}^{2}\right] \\
\text { Other } \\
\text { development } \\
{\left[\mathrm{km}^{2}\right]}\end{array}$ & $\begin{array}{c}\text { Zabudowa } \\
\text { handlowo- } \\
\text { usługowa }\left[\mathrm{km}^{2}\right] \\
\text { Commercial } \\
\text { and service } \\
\text { development } \\
{\left[\mathrm{km}^{2}\right]}\end{array}$ & $\begin{array}{c}\text { Zabudowa } \\
\text { jednorodzin- } \\
\text { na }\left[\mathrm{km}^{2}\right] \\
\text { Single-family } \\
\text { development } \\
{\left[\mathrm{km}^{2}\right]}\end{array}$ & $\begin{array}{c}\text { Zabudowa } \\
\text { przemysłowo- } \\
\text {-składowa }\left[\mathrm{km}^{2}\right] \\
\text { Industrial } \\
\text { and storage } \\
\text { development }\left[\mathrm{km}^{2}\right]\end{array}$ & $\begin{array}{c}\text { Zabudowa } \\
\text { wielorodzinna } \\
{\left[\mathrm{km}^{2}\right]} \\
\text { Multi-family } \\
\text { development } \\
{\left[\mathrm{km}^{2}\right]}\end{array}$ & $\begin{array}{c}\text { Suma } \\
{\left[\mathrm{km}^{2}\right]} \\
\text { Total } \\
{\left[\mathrm{km}^{2}\right]}\end{array}$ \\
\hline $13,8-15$ & 2,3 & 1,64 & 10,5 & 3,01 & 12,23 & 29,68 \\
\hline $15,1-17,1$ & 72,75 & 18,02 & 63,46 & 27,25 & 183,2 & 364,68 \\
\hline $17,2-19,2$ & 12,75 & 10,07 & 26,26 & 8,64 & 121,9 & 179,62 \\
\hline $19,3-20,2$ & 2,1 & 4,55 & 14,5 & 3,2 & 2,64 & 26,99 \\
\hline $20,3-22,2$ & 0,82 & 1,1 & 3,96 & 0,9 & 2,4 & 9,18 \\
\hline $22,3-25,2$ & 0,04 & 0,004 & 1,39 & 0,01 & 0,06 & 1,504 \\
\hline
\end{tabular}


Ślonej na podstawie danych z ANPR niż przy wykorzystaniu usługi Distance Matrix Responses (ryc. 4). Jednak ich rozległość oraz mało intensywne zagospodarowanie sprawia, że nie są to obszary, które w skali miasta należałoby uznać za znaczące (znajduje się na nich mniej niż 1\%o ogółu zabudowy mieszkaniowej i usługowo-handlowej oraz niewiele ponad $2 \%$ zabudowy przemysłowo-składowej). Najwięcej zabudowy znajduje się na terenie, którego różnica topologicznej dostępności określonej na podstawie analizowanych pomiarów mieści się w przedziale 6,9-8,9 min (44\% ogółu zabudowy mieszkaniowej jednorodzinnej, 53\% usługowo-handlowej, $58 \%$ mieszkaniowej wielorodzinnej i przeszło $61 \%$ przemysłowo-składowej) (tab. 5). $\mathrm{Na}$ terenach, gdzie różnica jest największa (wg danych ANPR przeciętnie jedzie się dłużej, niż wskazują na to dane z korporacji Google), nie zlokalizowano intensywnej zabudowy, stąd też, pomimo stosunkowo rozległego zasięgu przestrzennego izolinii (Złotno) nie ma tam wiele budynków.

Różnice w prędkościach poruszania się pojazdów określonych na podstawie prędkości kodeksowych i pomiarów ANPR są naturalnie dość znaczące i wynikają w głównej mierze z położenia dróg względem przebiegu granicy pomiędzy centrum

Tab. 5. Różnica pomiędzy wewnętrzną dostępnością transportową Łodzi określoną z wykorzystaniem danych z usługi Distance Matrix Responses świadczonej przez Google Maps APIs a ustaloną na podstawie modelu prędkości ruchu uwzględniającego pomiary z ANPR - kontekst zagospodarowania

Table 5. Difference between the internal transport accessibility of Łódź determined with the use of the data from the Distance Matrix Responses provided by Google Maps APIs and that determined on the basis of the traffic speed model taking into account the ANPR measurements - the context of land development

\begin{tabular}{|c|c|c|c|c|c|c|}
\hline $\begin{array}{c}\text { Różnica } \\
\text { średniego } \\
\text { czasu } \\
\text { [godz.] } \\
\text { Difference } \\
\text { in average } \\
\text { time [hrs.] }\end{array}$ & $\begin{array}{c}\text { Pozostała } \\
\text { zabudowa [km²] } \\
\text { Other } \\
\text { development } \\
{\left[\mathrm{km}^{2}\right]}\end{array}$ & $\begin{array}{c}\text { Zabudowa } \\
\text { handlowo- } \\
\text { usługowa }\left[\mathrm{km}^{2}\right] \\
\text { Commercial } \\
\text { and service } \\
\text { development } \\
{\left[\mathrm{km}^{2}\right]}\end{array}$ & $\begin{array}{c}\text { Zabudowa } \\
\text { jednorodzinna } \\
{\left[\mathrm{km}^{2}\right]} \\
\text { Single-family } \\
\text { development } \\
{\left[\mathrm{km}^{2}\right]}\end{array}$ & $\begin{array}{c}\text { Zabudowa } \\
\text { przemysłowo- } \\
\text {-składowa }\left[\mathrm{km}^{2}\right] \\
\text { Industrial } \\
\text { and storage } \\
\text { development [km²] }\end{array}$ & $\begin{array}{c}\text { Zabudowa } \\
\text { wielorodzinna } \\
{\left[\mathrm{km}^{2}\right]} \\
\text { Multi-family } \\
\text { development } \\
{\left[\mathrm{km}^{2}\right]}\end{array}$ & $\begin{array}{l}\text { Suma } \\
{\left[\mathrm{km}^{2}\right]} \\
\text { Total } \\
{\left[\mathrm{km}^{2}\right]}\end{array}$ \\
\hline$-0,3-3,2$ & 0,03 & 0 & 0,08 & 0,1 & 0,02 & 0,23 \\
\hline $3,3-6,8$ & 3,9 & 2,02 & 20,04 & 2,1 & 13,15 & 41,21 \\
\hline $6,9-8,9$ & 69,06 & 18,7 & 52,4 & 26,38 & 185,55 & 352,09 \\
\hline $9,0-11,0$ & 15,1 & 9,9 & 28,76 & 10,6 & 118,9 & 183,26 \\
\hline $11,1-13,6$ & 2,66 & 4,8 & 17,86 & 3,73 & 4,85 & 33,9 \\
\hline $13,7-16,0$ & 0,03 & 0,007 & 0,93 & 0,02 & 0 & 0,987 \\
\hline
\end{tabular}


miasta (wyznaczonego przez kolej obwodową) i jego peryferiami. Wspomniana oczywistość wynika z metody, jaką zastosowano, a więc metody szacującej prędkości (spowolnienie ruchu wynikające m.in. z braku jego swobody w miejskich układach) jako wartości względnej, zależnej od prędkości kodeksowej.

Różnice pomiędzy prędkościami poruszania się po sieci łódzkich dróg, uzyskane dzięki interpolacji wartości prędkości poruszania się na podstawie danych pochodzących z ANPR i Google, są nieco zastanawiające. Okazuje się, że w północno-wschodniej części miasta pojazdy poruszają się przeciętnie znacznie szybciej, niż wskazywałyby na to szacunki oparte na danych z ANPR. Wspomnianej nieścisłości nie da się wytłumaczyć podstawowymi charakterystykami danych usługi Distance Matrix Responses, które zapewne mają wpływ na różnice obserwowane na pozostałym obszarze miasta. Wygląda więc na to, że gęstość i przebieg dróg w tym rejonie oraz ich specyfikacja techniczna (która nie wiąże się z umiejscowieniem danej drogi w określonej kategorii) umożliwia uzyskanie większych prędkości przemieszczania się, niźli wynika to z prostego przełożenia wyników pomiaru ANPR na wszystkie obszary nieobjęte zasięgiem ITS.

$\mathrm{Z}$ uwagi na wspomniane przez nas na początku uwarunkowania, które wpływają na prędkość podróżowania kierowców, przyjęcie danej metody i jej wyniki należy interpretować, pamiętając o pewnych założeniach, które poczyniliśmy. W badaniach skorzystano z danych obrazujących prędkość przemieszczania się na ograniczonych przestrzennie odcinkach dróg. W powiązaniu z jedną z podstawowych cech przestrzeni geograficznej - jej zróżnicowaniem - może to powodować, iż rozciągnięcie analiz na całą zbiorowość odcinków może nie w pełni obrazować sytuację na łódzkich drogach. W badaniu starano się ograniczyć wpływ wspomnianego uproszczenia, chociażby poprzez określanie prędkości dla każdej z klas dróg. Poza powyższym pewnym uproszczeniem w tym zakresie jest także kwestia związana z uśrednianiem danych, a więc z nieuwzględnieniem indywidualnych cech każdego podróżującego i charakterystyk środka transportu. Ze względu na złożoność czynników przyjęto wartości średnie, uznając je za najbliższe prawdzie. Podobnie rzecz się ma w zakresie „uśredniania pory dnia”, dla której przedstawiono wyniki analiz.

Kolejną rzeczą, która wymaga komentarza, jest wykorzystana w badaniach metoda wyznaczania dostępności izochronowej. Poza pewnymi uproszczeniami wynikającymi z jej zastosowania (m.in. zasady interpolacji) przyjęto także, iż dostępność transportowa wyznaczana jest przy założeniu, że potencjalne przemieszczenia będą wykonywane w najbardziej racjonalny sposób. Oznacza to, że każdy z uczestników systemu dysponuje, po pierwsze, pełnym zestawem informacji o nim, po drugie, jest w stanie go przetworzyć i na ich podstawie zoptymalizować swoje ścieżki przejazdu.

Zastosowana metoda badania dostępności transportowej w ujęciu topologicznym powoduje istotny wzrost znaczenia położenia punktu w geometrycznej strukturze ośrodka w określeniu wewnątrzmiejskiej osiągalności. 


\section{Wnioski}

Zastosowanie w badaniach danych dotyczących czasu przejazdu pojazdów w łódzkiej sieci transportowej każe spojrzeć na łódzką sieć drogowo-uliczną jako na podsystem transportowy niezapewniający odpowiedniej podaży dla potrzeb transportowych. Sprawność lokalnego systemu transportowego, określona różnicą pomiędzy dostępnością mierzoną deklaratywnymi (kodeksowymi) prędkościami a wydającymi się być bliższymi rzeczywistości pomiarami, w szczególności z ANPR, należy oceniać bardzo słabo. Generalnie wewnętrzna dostępność transportowa Łodzi, w świetle danych ANPR, jest znacznie gorsza od dostępności teoretycznej oraz nieco gorsza (z nielicznymi i niewielkimi w rozumieniu przestrzennym i różnicy czasu wyjątkami) od dostępności mierzonej za pomocą danych z usługi Distance Matrix Responses. Należy przy tym zwrócić uwagę, iż ukazane różnice pomiędzy prędkościami z modelu opartego na ITS a prędkościami kodeksowymi są na swój sposób naturalne i wynik wskazujący na różnicę nie jest jedynym czynnikiem umożliwiającym ocenę sprawności systemu transportowego (w tym kontekście ważna jest kwestia wielkości tego spowolnienia, a nie sam fakt jego wystąpienia). Jest to wynik tego, że w miejskich sieciach transportowych nie występują odcinki, na których można by przyjąć taki stopień swobody ruchu, który nie powodowałby zmniejszenia prędkości rzeczywistej względem kodeksowej.

Największe różnice dostępności pomiędzy danymi z ANPR a pozostałymi dwoma metodami dotyczą przede wszystkim północno-zachodniej części miasta (mniej intensywnie zagospodarowanej), najmniejsze z kolei obszaru centralnego i południowego (tam, gdzie zagospodarowanie jest najintensywniejsze). Na terenach o najmniejszych różnicach pomiędzy zastosowanymi metodami występuje generalnie najwięcej zabudowy (z wyraźną dominacją zabudowy mieszkaniowej - głównie wielorodzinnej).

Różnice w zakresie średnich prędkości samochodów w łódzkiej sieci drogowo-ulicznej określone na podstawie trzech metod (prędkość kodeksowa, usługa Distance Matrix Responses, dane ANPR) wynikają przede wszystkim ze sposobu ich określania. $Z$ uwagi na zupełnie inne sposoby ich szacowania należy przyjąć, iż wynikają one przede wszystkim z:

- prędkości kodeksowej: określanej deklaratywnie na podstawie parametrów technicznych drogi oraz miejsca jej przebiegu;

- prędkości opartej na pomiarze z ANPR: jest pochodną prędkości kodeksowej i wielkości odchyleń rzeczywistych pomiarów z kamer względem prędkości kodeksowej na poszczególnych (wybranych na podstawie danych, które pochodzą z monitoringu) odcinkach klas dróg w określonych ich lokalizacjach. Wspomniane pomiary mogą nie być do końca reprezentatywne dla wszystkich odcinków łódzkich dróg. Wspomniany brak reprezentatywności może być wynikiem tego, 
iż monitoring ANPR jest wdrożony w miejscach szczególnie problemowych Z uwagi na duże obciążenie sieci drogowo-ulicznej;

- prędkości opartej o dane z usługi Distance Matrix Responses: metodologia ich pomiaru nie jest w pełni przejrzysta (dystrybutor danych informuje jedynie, że czas przejazdu pomiędzy dowolną parą punktów jest określony na podstawie wieloletnich obserwacji, nie wskazując jednoznacznie wag czasu przejazdu przypisanego pomiarom w zależności od czasu, kiedy one nastąpiły. Dostawca usługi nie precyzuje także w żaden sposób, z jakiej liczby pomiarów i z jakiego okresu dokonuje uśrednień wyników). Z tego względu trudno wskazać, na ile bliskie prawdzie są dane przez niego oferowane, zwłaszcza w zakresie zaprezentowanych tutaj analiz, które zostały przeprowadzone w trakcie trwania i tuż po zakończeniu wielkich inwestycji drogowych (m.in. niemal całkowita przebudowa trasy W-Z, budowa i przebudowa ciągów w rejonie nowego centrum Łodzi, liczne punktowe inwestycje w rejonach skrzyżowań z drogami stanowiącymi łódzki układ podstawowy), których wpływ był tak duży, iż wymaga nowego spojrzenia na mobilność, niekiedy w oderwaniu od historycznych zachowań transportowych mieszkańców miasta.

Z uwagi na powyższe, trudno jednoznacznie wskazać, która z zaprezentowanych metod jest bliższa prawdzie. Niemniej jednak, dzięki przeprowadzonemu badaniu możliwe jest wyciągnięcie wniosków i postulatów na przyszłość. Są nimi:

- poprawa jakości danych dotyczących tempa przemieszczania się w układach miejskich może nastąpić na skutek rozbudowy sieci monitoringu kamer ANPR, w tym instalacji wspomnianych narzędzi także na drogach, na których nie obserwuje się bardzo dużych obciążeń;

- poprawa jakości danych pochodzących z ANPR i sposobu ich przetwarzania. Wspomniana jakość z pewnością uległaby poprawie w przypadku: zwiększenia zagęszczenia detektorów oraz ulepszenia sprzętu hardware umożliwiającego efektywną pracę nad zasobami danych, które mieszczą się w pojęciu big data;

- wydaje się, iż w przypadku realizacji wyżej wymienionych postulatów, możliwe stanie się zobrazowanie ruchu oraz jego prędkości na podstawie modeli opartych na sztucznej inteligencji (sieci neuronowe), które umożliwiłyby nie tylko sprawniejsze i zautomatyzowane określanie przeciętnych prędkości opartych o dane empiryczne, ale także modelowanie wspomnianych zmiennych w oparciu o różnego typu wydarzenia oddziałujące na podsystem transportu samochodowego (remonty i związane z nim chwilowe wyłączanie ulic z eksploatacji, wydarzenia masowe, duże projekty związane z wprowadzeniem nowych generatorów ruchu samochodowego).

Badania przeprowadzone przez Autorów umożliwiają szersze spojrzenie na zasobność danych, które umożliwiłyby dokładniejsze badanie dostępności przestrzennej obszarów zurbanizowanych. W kontekście lokalnym są kolejną „,cegiełką” w badaniu przestrzennych wewnątrzłódzkich zależności. 


\section{Literatura}

Akcelik R., 1988, Highway capacity manual delay formula for signalized intersections, ITE Journal, Institute of Transportation Engineers, 58 (3), 23-27.

Bar-Gera H., 2007, Evaluation of a cellular phone-based system for measurements of traffic speeds and travel times: A case study from Israel, Transportation Research Part C: Emerging Technologies 15, 380-391. https://doi.org/10.1016/j.trc.2007.06.003.

Bartosiewicz B., Pielesiak I., 2012, Powiqzania transportowew Eódzkim Obszarze Metropolitalnym, Studia KPZK PAN, 147, 105-137.

Bateman I.J., Garrod G.D., Brainard J.S., Lovett A.A., 1996, Measurement, valuation and estimation issues in the travel cost method: A geographical information systems approach, Journal of Agricultural Economics, 47, 191-205.

Bateman I.J., Lovett A.A., Brainard J.S., 1999, Developing a methodology for benefit transfers using geographical information systems: Modelling demand for woodland recreation, Regional Studies, 33, 191-205. https://doi.org/10.1080/00343409950082391.

Borowska-Stefańska M., 2016, Dostępnośc transportowa od stra:y po:arnych do obiektów spotecznych zlokalizowanych na terenach «agrożonych powodziami w województwie tódzkim z wykorzystaniem analiz sieciowych, Transport miejski i regionalny, 3, 28-32.

Borowska-Stefańska M., Wiśniewski S., 2018, Dostępność tódzkich parków w swietle transportu indywidualnego, zbiorowego i rowerowego, Przegląd Komunikacyjny, 73 (2), 9-16.

Borowska-Stefańska M., Kowalski M., Wiśniewski S., 2019, Application of intelligent transportation systems in analyses of human spatial mobility in cities (w recenzji), Manuskrypt dostępny na Wydziale Nauk Geograficznych Uniwersytetu Łódzkiego.

Cauvin C., 2005, A systemic approach to transport accessibility. A methodology developed in Strasbourg: 1982-2002. Cybergeo.

Dąbrowska-Loranc M., Wojsz T., Bany P., Jankowska-Karpa D., Sicińska K., Wnuk A., Zielińska A., Nadowski A., Szyprowska M., Zieliński J., 2015, Prędkość pojazdów w Polsce w 2015 r. Sesja I, Warszawa.

Fröhlich P., Axhausen K.W., 2004, Sensitivity of accessibility measurements to the underlying transport network model [in:] Arbeitsberichte Verkehrs- und Raumplanung, IVT, ETH Zürich, Zürich.

Fröhlich P., Axhausen K.W., 2002, Development of car-based accessibility in Switzerland from 1950 through 2000: First results [in:] 2nd Swiss Transport Research Conference, Session (5) Accessibility. ETH Library, Monte Verità/Ascona, 12-19. https://doi.org/10.3929/ethz-a-010782581.

Gould P.R., 1969, Spatial Diffusion, T. 4, Washington, D.C.: Association of American Geographers.

Komornicki T., Śleszyński P., Rosik P., Pomianowski W., 2010, Dostępność præestræenna jako przestanka ksztattowania polskiej polityki transportowej, KPZK PAN, Warszawa.

Korkowo.pl, 2017, Raport-Ranking najwolniejszych polskich miast-wiosna 2017. Udostępniono: 6. wrzesień $2018<\mathrm{http}$ ://korkowo.pl/raport/ranking-najwolniejszych-polskich-miastwiosna-2017-705.>. 
Kowalski M., Wiśniewski S., 2017a, Dostępność transportowa tódzkich centrów handlowych, Handel Wewnętrzny, 3 (2), 339-357.

Kowalski M., Wiśniewski S., 2017b, Natę̇̇enie ruchu a zagospodarowanie Łodzi-zarys problematyki w swietle danych z Obsæarowego Systemu Sterowania Ruchem, Prace Komisji Geografii Komunikacji PTG, 20 (4), 20-36.

Lamprecht M., Wojnarowska A., 2013, The structure of urban space in Łódz [in:] M. Habrel, A. Wojnarowska (eds.), Lviv and Łód at the turn of 20th century. Spatial development and functional structure of urban space, Uniwersytet Łódzki, Łódź.

Radzimski A., Gadziński J., 2016, Jak transport publiczny wptywa na ksztattowanie się rynku nieruchomości? Przyktad Poznańskiego Szybkiego Tramwaju, Prace Komisji Geografii Komunikacji PTG, 19 (3), 34-45.

Rosik P., 2012, Dostęnność lqdowa przestrzeni Polski w wymiarze europejskim, IGiPZ PAN, Warszawa.

Stępniak M., Rosik P., Komornicki T., 2013, Accessibility patterns: Poland case study Europa XXI 24, 77-93. https://doi.org/10.7163/eu21.2013.24.6.

Śleszyński P., 2014, Dostęnnośćcæasowa i jej zastosowania, Przegląd Geograficzny, 86 (2), 171-215.

Śleszyński P., 2016, A synthetic index of the spatio-temporal accessibility of communes in Poland, Geographia Polonica, 89, 567-574.

Wiśniewski S., 2014, Dostępność transportowa Uniejowa - ujęcie regionalne, Biuletyn Uniejowski, 3, 67-84.

Wiśniewski S., 2015, Zróśnicowanie dostępności transportowej miast w wojewódætwie tódækim, Uniwersytet Łódzki, Łódź.

Wiśniewski S., 2016, Teoretycæna i ræeczywista wewnętræna dostępność transportowa Łodzi, Prace i Studia Geograficzne, 61 (3), 95-108.

Borowska-Stefanska Marta

Uniwersytet Łódzki

Wydziat Nauk Geograficznych

Instytut Zagospodarowania Środowiska i Polityki Præestrzennej

ul. Kopcińskiego 31, 90-142 Łódź

marta.borowska@geo.uni.lodz.pl

Kowalski Michat

Uniwersytet Łódzki

Wydziat Nauk Geograficznych

Instytut Zagospodarowania Środowiska i Polityki Przestrzennej

ul. Kopcińnkiego 31, 90-142 Łód:

michal.kowalski@geo.uni.lodz.pl

Wisniereski Szymon

Uniwersytet Łódzki

Wydziat Nauk Geograficznych

Instytut Zagospodarowania Środowiska i Polityki Przestræennej

ul. Kopcinskiego 31, 90-142 Łódź

szymon.wisniewski@geo.uni.lodz.pl 